\title{
TV/Series
}

$13 \mid 2018$

Diziler : les séries télévisées turques

\section{Genre strikes back: conspiracy theory, post-truth politics, and the Turkish crime drama Valley of the Wolves}

Josh Carney

\section{(2) OpenEdition}

Journals

Electronic version

URL: http://journals.openedition.org/tvseries/2467

DOI: $10.4000 /$ tvseries.2467

ISSN: 2266-0909

Publisher

GRIC - Groupe de recherche Identités et Cultures

\section{Electronic reference}

Josh Carney, « Genre strikes back: conspiracy theory, post-truth politics, and the Turkish crime drama Valley of the Wolves », TV/Series [Online], 13 | 2018, Online since 03 July 2018, connection on 19 April 2019. URL : http://journals.openedition.org/tvseries/2467 ; DOI : 10.4000/tvseries.2467

This text was automatically generated on 19 April 2019

\section{(c) $(1)$}

TV/Series est mis à disposition selon les termes de la licence Creative Commons Attribution - Pas d'Utilisation Commerciale - Pas de Modification 4.0 International. 


\section{Genre strikes back: conspiracy theory, post-truth politics, and the Turkish crime drama Valley of the Wolves}

Josh Carney

\section{EDITOR'S NOTE}

I thank the organizing committee for the 2014 Paris conference on Turkish TV series for providing me an occasion to present an early version of this work, and Barbara Villez for her patience and guidance on this piece. This research was made possible by support from the Wenner Gren Foundation, the Mellon Foundation, and a postdoctoral fellowship at the University of South Florida.

1 In early October, 2016, Turkish production company Pana Film released a statement to television and the Internet in attempt to curtail a broiling scandal over a web site they had recently acquired. Pana had purchased the rights to the domain kurtlarvadisidarbe.com, which translates to "valley of the wolves coup," in May, two months before a failed attempt by portions of the military to topple the ruling Justice and Development Party (Adalet ve Kalkinma Partisi - AKP). While this might pique interest in any circumstances, both fans and critics of the then thirteen-year-old Valley of the Wolves ([Kurtlar Vadisi], Show TV, 2003-20051) franchise were particularly intrigued because the show has a reputation for uncovering conspiracies and revealing truths about politics and power in Turkey ahead of the curve. Many fans assume the producers have inside knowledge about key events well in advance of the general public.

2 Speculation about why and how Pana Film had known to purchase the web site compounded the already rife rumors regarding who had plotted the coup. It was not long before TV talk show hosts Nihat Doğan and Ömür Varol began a campaign on their daily 
morning show Can't Not Say It ([Söylemezsem Olmaz], Beyaz TV) to have Valley investigated for potential involvement in the coup. The campaign was outrageous on many fronts: it extrapolated from the web site purchase and posited wildly implausible conspiracies including secret messages transmitted through years-old programs and mind control based on the series' soundtrack. It relied heavily on visual evidence that clearly negated the claims being made and was, furthermore, based on false information. It also appeared to be tied directly to corporate motivations, since the channel airing the accusations, Beyaz TV, had just lost the contract to broadcast Valley reruns. Beyond this, when the Pana Film team eventually did release a statement answering the accusations, Doğan and Varol merely shifted the target of their inquiry, transforming Valley plot points into new would-be conspiracies. As ridiculous as the claims were, they found audience in the fertile paranoia of the State of Emergency (Olağanüstü Hal - OHAL) in post-coup Turkey and, within a week, a prosecutor took up the hosts' invitation to open an investigation.

This decision was not without irony, since Valley played a formative role in preparing the way for such paranoia and, in a greater sense, in fomenting a nexus of nationalism and post-truth politics that have been key to the AKP's continued rule. This atmosphere relies heavily on the logics of conspiracy theory and, in the argument that follows, I trace these logics in Valley and among its publics by braiding three strands of evidence: the Valley text itself, media discourse about Valley, and observations from interviews and encounters with Valley viewers that arose amidst ethnographic fieldwork ${ }^{2}$. I turn first to the question of conspiracy theory as genre, and demonstrate how the genre norms that Valley had standardized were turned against the show by the Can't Not Say It affair. Though the exploration of genre gives us a chance to examine some of the key logics of conspiracy theory, the function of such theory is also tied to its performative uses, and I next turn to the Foucauldian notion of enunciation to explore this. Finally, I touch on conspiracy theory as it circulates in the era of so-called post-truth politics, suggesting that the trust in simple truth to combat such theory may be misguided.

\section{Conspiracy theory as genre in Valley}

4 Valley premiered as a television serial on private channel Show TV in January of 2003. It relates the story of Polat Alemdar, a Turkish secret agent who infiltrates the Turkish mafia in order to destroy it in the first TV series, and then moves on to tackle other enemies of the Turkish nation, be they local or international. Polat works with a small team of men (and, later, women), sometimes with the cooperation of the state, and sometimes against corrupt elements of its bureaucracy. Valley has thus far spanned three TV series that garnered consistently high ratings on TV and online, and five feature films. Over the fifteen years since it first aired, Valley has established a host of norms in its patterns of communication with fans, a number of which were activated and reversed by Doğan and Varol in their autumn attack on Valley.

5 These norms are not unique to Valley but, rather, draw on and contribute to a larger body of conspiracy theory that has been subject to a great deal of study. Among the branches of this theorizing about conspiracy theory, I mark three broad trends: the typological, which aims to distinguish the norms of the conspiracy theory argument; the interpretive, which aims to consider the broader reasons for and meaning of conspiracy theory in the human condition (e.g. Comaroff and Comaroff, Fenster, Jameson, West and Sanders ${ }^{3}$ ); and the conspiracy-oriented, which focuses on the prevalence of actual conspiracy, and attempts 
to relate this to conspiracy theory (e.g. Marcus ${ }^{4}$ ). In what follows I focus primarily on the typological, referring in particular to the work of Richard Hofstadter ${ }^{5}$, who discusses the "paranoid style" of conspiracy theories, Earl $\mathrm{Creps}^{6}$, who examines their "rhetorical genre", and Jovan Byford", who describes the "anatomy" of such theories. Though I here make use of typologies, my interest in conspiracy theory is ultimately interpretive, and it is for this reason that I adopt Creps' term "genre" when speaking of the norms of the conspiracy argument.

6 I employ genre not as a formal category but, rather, in line with Briggs and Bauman', drawing on Hanks", as "an orienting framework for the production and reception of discourse $\mathrm{e}^{10}$." Such a conception allows us to consider genre as a means for a multitude of discursive operations, bridging the gap between texts and those who use them. Indeed, Karin Barber calls genre "the pivot between the producer and receiver of a text ${ }^{11}$." Though the argument to follow relies heavily on norms established within the Valley text itself, my ultimate interest is in the circulation and use of conspiracy theory among the publics who access and relate to Valley, and here I draw on Michael Warner's conception of a public as a self-organized, text-based social space created by the reflexive and temporal circulation of discourse among strangers ${ }^{12}$. Though Valley evinces a host of genre norms in accord with the typological approaches highlighted above, for the sake of brevity, I lump these into three rough groups: shifts in loyalty; the rhetoric of asking questions, giving voice to others, and revealing truths; and, finally, the nature of the "truth" revealed by conspiracy theory logic.

7 Most obviously pertinent to the Can't Not Say It debacle is the norm of radical shifts in loyalty. At the plot level, Valley normalized stark turns in the behavior of key characters, such that a friend one week might be an enemy the next, and vice versa. The transformation of a character known as Kara, who joined the third television series Valley of the Wolves: Ambush during season six (2011-2012), provides one case in point. Kara, who is loosely based on real-life MiT (Millî İstihbarat Teşkilâtı - National Intelligence Corps) agent Mahmut Yıldırım (code name "Yeşil"), is initially portrayed as a villain. Shortly after being introduced to the plot (episode 129), he assassinates Alper, one of Polat's associates in the intelligence service (episode 131), and then Hamit, a man that Polat is charged with protecting (episode 132). Over time, however, Polat and Kara come to realize they have both been betrayed by the same forces, and they become closest allies. Other key examples include the shifts in loyalty (and sympathetic portrayal of) Zaza Dayı a sometimes nemesis, sometimes ally; key members of the Council of Elders (ihtiyarlar Heyeti), who are supposed to direct Polat in the interests of the state, but sometimes betray him; and even Abdülhey, one of Polat's most trusted men, who shifts loyalties while under the influence of mind control treatment.

One "lesson" from such twists in plot is that no one is to be trusted fully. Loyalties can shift on a moment's notice due to circumstances of national or supranational importance that are far beyond the control of any single character. Indeed, though Valley reinforces this lesson textually on a regular basis, it has also done so extra-textually at times. Numerous long-time viewers of the show spoke to me about the changes in "message" and "stance" that the show took with its various shifts between channels over the years and, given the clientelist media model prominent in Turkey ${ }^{13}$, this is hardly surprising. At a more personal level, the proclivity for radical shifts in loyalty was reinforced with the high-profile feud that took place between Pana Film's two key figures in 2013: producer Raci şaşmaz and his older brother, Necati şaşmaz, who plays Polat Alemdar on the show. 
In the wake of the feud, which saw Raci leave the Pana team, long-time writers and key actors also left, suggesting that bonds formed over years of working together could be as fragile and liable to shift as those portrayed in the show.

9 This same language of loyalty shifts is deftly employed by Doğan and Varol in the following exchange on their first discussion of the "controversy" over Valley:

NIHAT DOĞAN. Some of our viewers are writing to say, look man, Valley of the Wolves is the state's show-it's on the side of the state.

ÖNÜR VAROL. Which state?

NIHAT DOĞAN. Statist? FETÖ was statist as well: the, in quotation marks, PiÇ, paralel ihanet çetesi [parallel treachery gang], the parallel state structure, that is, the state within a state ${ }^{14}$. Were not Ramazan Akyürek, Ali Fuat Yllmazer, soldiers, prosecutors, judges, and those who bombed the people the state? They were the state itself ${ }^{15}$.

10 To provide some basic context, "FETÖ" is the acronym for Fethullahçı Terör Örgütü (Fethullaist Terror Network)-the AKP government's name for the organization linked to Islamic Scholar Fethullah Mthat presumed to be behind the coup attempt ${ }^{16}$. Doğan uses a slang acronym, "Piç," to refer to this group because the Turkish word "piç" is the insult, "bastard." Akyürek and Yllmazer are intelligence operatives working for the state who are alleged to be members of the Fethullaist network, and to have had a role in the assassination of Armenian journalist Hrant Dink in 2007. Doğan's point is clear: there is no way to tell who is on what side, so the Pana team could well be enemies of the state.

11 Valley's plot had made direct and clear reference to Gülen and his network as enemies of the state, involved in attempts to "clone" the state structure from within, and to bring down the government, since 2014. Indeed episode 218, which aired early that year, references and reenacts the three key aspects of what the AKP had already started calling a "coup" in late 2013: the highly public opening of prosecution cases against a number of key AKP party members for corruption, the public leaking of wiretap tapes to demonstrate this corruption, and the "truck scandal," in which Gülen loyalists in the military prevented Turkish intelligence operatives from taking arms to Syria, allegedly to support Turkmen opposition to the Asad regime. The series even created a character based on Gülen called Muhterem Bey. Given Valley's explicit casting of the Gülen Movement as an enemy, completely in line with the AKP take on the so-called "parallel state," it is hard to understand how Varol and Doğan could implicate the franchise in the coup, but the norm of shifting loyalty established by Valley may well have prepared the way. Indeed, the ability of the conspiracy argument to accommodate a shift between enemies is one of the hallmarks that Earl Creps has identified in the conspiracy theory genre ${ }^{17}$.

Doğan and Varol do not directly accuse Valley of participation in the coup attempt; instead, they frame their task in terms of asking questions (and demanding an answer from Pana Film), providing a platform for others to speak (especially their audience members), and revealing truths (particularly through visual evidence, including documents, scenes from Valley, and on-the-scene investigation of Valley filming locations). It is this same language that Valley and its creators often employ when defending their work. Speaking on the talk show Uncensored [Sansürsüz], airing on proAKP channel 24 in 2012, Valley writer Bahadır Özdener explained to host Yiğit Bulut (now a senior advisor to President Erdoğan) why Valley poses questions that no one else is willing to ask by using a parable: 
Yiğit Bey ${ }^{18}$, when we're speaking about media there's a basic rule. There's a room with five monkeys and there's one banana hung in it. The first monkey tries to get it and he's sprayed with water. The second tries and he's sprayed with water too. After that, the others don't try, and even if others are added to the room the previous monkeys prevent them from trying. Even when the old monkeys are all switched out none of the monkeys (which weren't victims of the water) is brave enough to get the banana. Our young friends who enter the media are not told what to do, They're told what topics not to touch on. This isn't a didactic lesson, it happens little-by-little with courtesy. You can't write a real history of our press because it doesn't have a real history. Unfortunately it's beholden to the hegemony, and the state never supported a good press. The worst facet of this is the youth losing the ability to ask real questions ${ }^{19}$.

Both Valley's producers and its viewers agree that the show asks the "necessary" questions that others in Turkey are ignoring and, indeed, the rhetoric of "just asking questions" is among the norms identified by Jovan Byford in the anatomy of conspiracy theory ${ }^{20}$.

Closely related to the issue of asking (and getting fans to ask) the tough questions, Valley's producers often explain their role as taking the side of the oppressed. Speaking on news channel Habertürk during the promotional tour for the fourth Valley cinematic spinoff, Valley of the Wolves: Palestine, director Zübeyr şaşmaz and his older brother Necati explained their goals from a photographic standpoint. Palestine finds Polat and his team heading to Israel/Palestine after the Mavi Marmara flotilla raid in 2010 to kill the Israeli commander responsible for the raid. Noting that the treatment of Palestinians depicted in the film is based on facts from the Goldstone report, Zübeyr said that the Pana Film team wanted to "take photographs" of reality and show them back to the people:

ZÜBEYR. It's like the difference between CNN and Al Jazeera: are you on the side that drops the bomb, or the side where it lands? A war photographer's situation is similar: you don't want a war, but you can only do your job when there's a war. It's the same situation for those making this kind of film: you're obliged to take a picture and that's what you do.

NECATI. But, for the sake of security most people stay on the winning side. That's true of the press and it is generally true of filmmakers as well. We're doing something different. We're one of the first large scale operations playing to a wide audience to take the weaker side. We show where the bomb landed ${ }^{21}$.

Necati expanded on this point in a later interview with journalist Can Dundar: "We are on the side of the oppressed in all situations, regardless of their religion or race. [...] Our target audience is all people, to let them hear this sound, to tell this story. This is a good action to take ${ }^{22}$." While presenting a Palestinian side to the Israel/Palestine issue could clearly be justified as taking the side of the oppressed, Necati's claim that Valley does this "in all situations" would appear to display, at best, deep political naiveté. The show's portrayal of the Kurdish rights struggle, for instance, is far from sympathetic: its ultranationalistic take was so controversial that the second Valley TV series, Valley of the Wolves: Terror, was removed from the air after just one episode. Similarly, despite Necati's denial of religious interest, Valley makes a clear point of demeaning Jewish and Christian characters, often casting them as the worst sort of villains and, in the case of Jews, portraying a host of common racist stereotypes as well.

But while Necati's statement could be read as a cynical marketing line, it could also be taken as a literal description of the way the Pana team sees their project-that is, as part of a greater struggle in which they are, a priori, defined as the weaker side. This notion is 
certainly in line with the so-called Sèvres Syndrome that operates among many in Turkey, and also animates the narrative structure of the show ${ }^{23}$. The name of this "syndrome" refers to the infamous Treaty of Sèvres (1920), in which the remnants of the Ottoman Empire were to be divided amongst European powers at the conclusion of the First World War, leaving only a small fraction of the land for an emergent Turkey. Turkey's “independence struggle" was fought against Greece to prevent this outcome, but the lasting cultural impact of this threat, reinforced through education and media, has been an entrenched belief that only Turks will stand up for Turks, and that other nations are constantly looking to divide and conquer the country. Such a belief would be in line with what Richard Hofstadter has identified as the "paranoid style" that characterizes conspiracy thinking. In particular, Hofstadter notes that conspiracy theorists tend to conceive of their enemies as much stronger, "forces of almost transcendent power ${ }^{24}$ ".

Inherent in both the issue of posing "real questions" and "taking the side of the oppressed" is the assumption that Valley's project is somehow related to truth. Indeed, the franchise's reputation is based heavily on its presumed depiction of realities that others dare not show. A number of viewers told me that Valley was an outlet for news stories that cannot be printed, with one suggesting that sources would leak information to Valley writers rather than reporters, because the writers were more trusted (May, 2013). Another told me that "ninety percent of what you see on Valley is true" (October, 2014) and, while few viewers actually attempted to quantify the truth value of the show, the sentiment, if not the number, was largely reflected by others.

Though Valley has often steered clear of overt claims-indeed, each episode of the TV serial begins with a disclaimer directly rejecting such claims-they have at times capitalized on this reputation, as in the promotional trailer for the premier of Valley of the Wolves Ambush season eight, released in the fall of $2013^{25}$. It begins with a brief encounter from the previous season between Polat and a character named Ronald. The latter is a member of the Templars, a powerful secret society who are fighting to bring about a new world order, and who constantly thwart Turkey's progress:

POLAT. Turkey is moving forward to become a world power, why don't you understand this?

RONALD. Your economic and military power is far too little for your goals.

This is followed by news footage of conflicts throughout the Middle East, including General Sisi taking power in Egypt, soldiers marching on mountain trails, and skirmishes between police and protestors during the Gezi Park Movement. Then the screen goes blank, only to be replaced by penguins. A voiceover intones: "well, if you don't want to watch penguins, watch the facts on Valley of the Wolves."

The penguins are a reference to the blackout of news regarding the Gezi Park protests on Turkish news channels during the summer of 2013-particularly to CNN Türk's decision to broadcast a penguin documentary while CNN International carried news of the protests live ${ }^{26}$. The intermingling of Valley text and news footage, alongside a reference to the shortcomings of Turkish news reporting has a clear implication: Valley is the place to come for the facts that you will not get elsewhere about what is happening, and about Turkey's role in the world.

21 Though the "facts" are certainly important, my encounters with viewers lead me to believe that it is the narrative weft among which these facts are interspersed with rumor and speculation that is ultimately the most salient aspect of the show, providing a transcendent "truth" of sorts that offers order in a chaotic world. This order is the logic 
of conspiracy, and it is the underlying premise and structure of the Valley franchise. There is no shortage of examples. In the just-mentioned trailer, for instance, the framing of crisis moments by a scene with the Templars suggests, in keeping with the narrative line of the serial, that the Templars purposely quashed the Arab Spring, supported the PKK, and instigated the Gezi Park protests in order to frustrate the "return" of Turkish prominence to the world stage.

I have touched briefly above on some aspects of conspiracy genre that populate Valley and the discourses surrounding it, referring, alternatively to the work of Creps, Byford, and Hofstadter. Hofstadter was one of the first to tackle questions of conspiracy theory from an academic standpoint, and among the key tenets of style he identifies are the notion of a "vast and sinister conspiracy" operating via "subtle machinery 27 ", a pedantic concern on the part of the theorist with exhaustive demonstration of his or her points ${ }^{28}$, and leaps in imagination between supporting facts and conclusion ${ }^{29}$. Creps expands on Hofstadter's work, adding a number of other key tenets, including the above-mentioned flexibility of the conspiracy argument to accommodate new enemies and/or subjects ${ }^{30}$. Byford also hearkens back to Hofstadter in his more recent typology of the norms of conspiracy theory, including among these that such theories reveal "a single, overarching plot which supposedly explains everything ${ }^{31}$ " and acts as "a motive force in history"32"; that the conspirators work via a system of "hidden messages in political speeches, newspapers, and on TV ${ }^{33}$ "; and, crucially, the importance of foreknowledge about key events ${ }^{34}$. In each of these cases, the authors strive to characterize the norms of the conspiracy theory genre. All three also mention the high prevalence of anti-Semitic stereotypes and casting of Jews as chief conspirators in a global order.

Several of these genre norms are important in establishing the transcendent truth of conspiracy logic that ties together Valley and its diverse subplots. The assumed role of hidden messages, for instance, has been key to Valley's logic from the outset. In the first series, Polat routinely looked in the newspaper for clues that would be posted there either as a message to him by, for example, Aslan Bey, his key contact in intelligence services, or as a message to others that he could intercept in order to foil a plot. Years later, the above-mentioned character Kara was introduced to Ambush in the same way, hunting through newspapers for clues and clipping them out (S06, E129). Likewise, the importance of foreknowledge about key political events is something many fans refer to in explaining Valley's value. Though it was often difficult for fans to point to specific instances when I pressed for examples, multiple informants told me that the show "predicted" that the death of President Turgut Özal in 1993 may have been an assassination. Valley began treating Özal's death as an assassination with the first episode of Ambush in 2007, and then proceeded to show the "details" of the crime in the film Gladio, which came out in 2009. Though there had long been rumors of an assassination, Valley was credited with "predicting" the "truth" when the government opened the death up for investigation again in 2014 35 .

24 A number of the other hallmarks of conspiracy logic are displayed in the second episode of season 9 (E231), one highlight of which is Andy Garcia reprising his 2005 role as a character called Amon, to lecture Polat on the nature of the "new world order ${ }^{36 "}$. Elsewhere in the episode, Polat sits in front of a chalkboard filled with key events from 2001-2014 and we hear a voiceover of his internal monolog as he ties together the World Trade Center attacks of 2001, the US detention of Turkish soldiers in northern Iraq in 2003 , the bombing of a consulate, synagogues, and a bank in Istanbul later that year, and 
the formation of şEDiD, the Valley equivalent of the Islamic State. These events are shown to have a cohesive internal logic tied both to the long-term Valley plot (e.g. the assassination of key character Mehmet Karahanlı in 2003), and to the greater global power structure. Editing suggests that England's "Prince Henry" is part of a dynasty that still runs the corporations that control various states, and that he is also the ultimate power behind the Islamic State.

Valley ultimately phased out the Henry character, displaying the flexibility in terms of enemy norm noted above by Creps, but there was no departure from the "vast and sinister conspiracy" united by a "single overarching plot" and acting as a "motive force in history," which are all key aspects of the conspiracy argument. Furthermore, we can see very clearly the leaps in imagination from evidence to conclusion, which take place for Polat at the chalkboard.

Each of the genre traits identified above can also be seen in the Can't Not Say It approach to Valley. The initial "evidence" cited by the show for Pana Film's suspicious behavior was the fact that the company had purchased the rights to the web site kurtlarvadisidarbe.com (valleyofthewolvescoup.com) two months prior to the 15 July coup attempt. This was quickly bolstered with a claim that the appearance of the name "Erdoğan" on a gravestone in the background of a cemetery scene from a 2012 episode (S06, E159) should be read as a coded message about the downfall of the former Prime Minister, now President of the country, Tayyip Erdoğan ${ }^{37}$. Indeed, the following day the show sent a film crew to a cemetery to "expose" the fact that the gravestone in question had been changed ${ }^{38}$. Varol claims that staff at the cemetery attest to Valley's filming there, but if one watches the talk show carefully, stark differences between the cemeteries in question are clear: a worn-out sidewalk fronts the gravestone in the Can't Not Say It clip, while there is none in the Valley episode; the two scenes feature an entirely different backdrop, with a forest in the Valley scene and more cemetery in the Can't Not Say It clip; even the gravestones in question are physically different, though Doğan and Varol explain this as the intentional alteration by Valley; finally, there is an obvious difference in the gravestones behind the grave, suggesting in line with all of the above that the show had found the wrong spot.

Pana Film released a statement the following day explaining that the web site had been purchased in line with the broader concept of a "coup" by the Gülen Movement, noting as well that the government had been using the term "coup" to refer to the Movement's actions since 2013. Furthermore, they noted that the Can't Not Say It crew had, indeed, gone to the wrong site, though cemetery staff had not been lying: Valley had filmed an episode at the site investigated by the show-as many episodes feature cemeteries-it had just been a different episode. They further explained that the gravestone in question could still be found very easily in another cemetery and that it does say "Erdoğan."

These replies did little to dissuade the hosts of the talk show, who simply shifted their attacks, claiming two days later that Valley still must have highlighted the Erdoğan gravestone for a reason. They then moved to a different episode of Valley to reveal "clues" about the show's ulterior motives. Claiming that the ezan (Islamic call to prayer) was read backwards in the trailer to season 10 (2015), they had three religious experts on to interpret the meaning of a reverse ezan, suggesting that it may have been both a sin and an attempt at casting a spell on viewers. It is first worth noting that Can't Not Say It does not by any means establish that the ezan was actually read backwards. Nonetheless, Valley 's clear tendency to highlight hidden messages within its plot line works against the show 
here, as host Varol notes "we highlight these sorts of details because this is an 'operational' serial that has been giving these kinds of hints regularly for 13 to 14 years $^{39}$ ." Indeed, Valley had even made a plot point about altered ezan calls being used to encourage conversion to Christianity in the spring of 2014 (season 8, episode $221^{40}$ ).

Another such "detail" from the season 10 trailer allegedly relates to Israel. Polat discovers a dead priest when he goes to a church in Cyprus and, as he leans down to examine the body, an elongated pool of blood coming from the priest's head is visible on screen. Doğan and Varol claim that this blood puddle is in the shape of Israel, and Doğan goes on to extrapolate that this must be a message about how the Gülen Movement is linked to Israel, Zionism, the division of the Middle East, and the coming of a new world order. That the blood puddle in question only resembles Israel insofar as both are somewhat elongated may by now go without question, but we see here both the pedantic concern for detail and the leaps of imagination highlighted by Hofstadter.

\section{Enunciating cracks in the story}

30 If the brief survey above has demonstrated that Valley was plagued by the genre norms it helped establish, it also hints at the weak nature of some of the claims related to the show. Indeed, a mildly alert observer could see clearly that the visible evidence presented in no way matched the claims it was meant to support. Though the conspiracy theory phenomenon at work in Valley and its greater public is complex, and has many avenues worthy of exploration, I focus here on this intriguing disconnect between claims and the evidence that supports them. For Doğan and Varol were far from the only members of Valley's public to make outlandish claims.

31 I met one member of this public, whom I will call Aşkın, at a social event in October of 2014. This was a tense period in Turkey, as the Kurdish People's Protection Units ( Yekineyên Parastina Gel - YPG) in Syria were fighting to defend the town of Kobane against the Islamic State, and President Erdoğan had done all in his power to prevent those in Turkey from assisting in the defense, either by sending goods or crossing the border to provide support. His rationale was that the YPG was affiliated with the PKK and, therefore, that any assistance to their cause was assistance to terrorists. While Erdoğan was far from alone in his take on the situation, many in Turkey felt that the Islamic State was a greater threat than the YPG or even the PKK, and some Kurds and their allies also felt inspired by the YPG and its project of a stateless autonomous rule in Rojava (Kurdishcontrolled Northern Syria). Aşkın was not among the latter group.

32 I had been speaking to our mutual friend, whom I had known for years, about Kobane when Aşkın intervened in the conversation. The friend introduced us and, when Aşkın learned that I was an American studying, among other things Valley, he struck a tone that I can only call deliberately combative while proceeding to lecture on what was "really" going on in Kobane. Among his claims were that the PKK contained very few Kurds-that the force was, rather, composed almost entirely of French, Germans, and Italians-and that the Islamic State was a deliberate creation of the US and Israel. His account was exhaustive, but I was not expecting to interview at that event, and neither did I ask his permission to record, so many of the details are now lost. Ultimately, however, he claimed that the "battle" for Kobane was no battle at all, but rather an elaborate charade to steal oil and undermine Turkey's integrity. "And so," he concluded, "you see more than 
ninety percent of what they show on Valley of the Wolves is true." I laughed at this, but he repeated the claim, adding, "I'm serious, it may sound a bit crazy but the show really gets it right ${ }^{41}$."

One thing that I found striking about this encounter was Aşkın's mode of engagement. Each statement seemed to me to be delivered as an angry but nervous challenge against what I can only assume Aşkın perceived as my default "American" point of view on the world. He leaned towards me, adopting a stern, lecturing tone of voice that gave no pause for dialog, and used his finger to point at me when referencing the US. His gaze alternated between a smoldering stare and what I perceived to be a search for confirmation-as if he wanted to gauge the effect of this performance on me.

This interaction took place just weeks after the broadcast of episode 231, which I highlight above in terms of conspiracy logic and truth. Valley's presentation of the Islamic State (or, as the show calls it, şEDiD) might be interpreted as in line with what Aşkın says, as there is little doubt either in the show or the real world that US interests in the region have much to do with oil. (In Valley, the immediate force behind şEDiD seems to be a company in the UK tied to the British Royal Family, but it is not entirely clear how this links to more distant forces, and the US and Israel often feature as part of the ultimate enemy in Valley plots.) But while Valley presents a complicated picture of the PKK and its motives, the show's portrayal does not mesh with Aşkın's account of a force composed mainly of Europeans. That is, it is hard to see why Aşkın would share this theory about the PKK, which goes directly against well-publicized facts about the organization and against Valley's representation of the organization, while claiming the show was mostly true. Placing Aşkın's insistence on the "ninety percent" truth of the show next to his performative engagement, however, I think his aim may have been provocation rather than a claim to referential accuracy.

In a discussion of so-called "White nihilism" among "hooligans" participating in a controversial annual pigeon shoot in the US, ethnographer Hoon Song notes that the hooligans he met were also conspiracy theorists who embraced absolutist theories despite clear deficiencies in their claims. Part of the reason for this, he suggests, is to provoke:

Conspiracy theorists are not essentialists despite themselves; they actively choose to be so. They are militantly disinterested in the ideas of "partial truths", of the contingency of meaning, of the Foucauldian wisdom that their version might be merely one of many "regimes of truth". Instead, stigmatization only breeds claims to even Bigger Truths. [...] Much more than a referential claim, their "theory" is an apparatus that provokes ${ }^{42}$.

For Song, a key element of the conspiracy theory is that inevitable moment when a propositional claim loses referential validity. When the evidence cannot sustain the claim. Something "escapes capture" at this moment, and this escape is best characterized by the Foucauldian concept of enunciation, which "refers to the event of discourse, not to its 'content'; to its taking place, not to the text of what is stated ${ }^{43}$ ".

Many thinkers on conspiracy theory working in what I have called the interpretive tradition highlight the apparent rise and spread of such theorizing as a reaction to the socalled postmodern condition: the conspiracy theory provides an overarching logic to account for the loss of master narratives and give the self a sense of place in an otherwise fragmentary world. But Song's observation on enunciation in the circulation of conspiracy suggests something important about this would-be master narrative: 
conspiracy theory may not be so much a replacement as it is a new sort of narrative, one in which the cracks in the story are clear, and are alternately invitation or provocation.

\section{Post-truth politics, factishes, and the stakes of conspiracy}

In contemporary Turkey, these cracks may serve as invitation, for example, to the roughly half of the population who accepts Erdoğan's repeated assertions that any difficulties in the economy stem from the manipulation of a "finance lobby" bent on quashing Turkey's rise to prominence. There is no evidence for such a lobby and, indeed, much to the contrary to suggest that it is Erdoğan's political and economic policies that have damaged the economy. Nonetheless, both Erdoğan and Valley attest to such a lobby, inviting and provoking others to speak of it, as if repetition will conjure its existence ${ }^{44}$.

And, in an era that is increasingly referred to as that of "post-truth" politics, this may be true, in a sense. Bruno Latour has introduced the notion of a "factish"-a curious hybrid between fact and fetish that hearkens back to the time before humans purported to be modern, when belief was not opposed to fact ${ }^{45}$. For Latour, who holds that we never really could be modern-that we could never shake the importance of belief and merely transferred that belief from religion to fields such as science, ignoring that they were just as constructed in many ways-the factish represents a possibility to heal the modern break between what is "real" and what is constructed:

The solution of the factish is not to ignore the choice [between reality and construction], as so many postmoderns will do by saying: "Yes, of course, construction and reality are the same thing; we know that everything is illusion and make-believe." The factish says something else: It is because it is constructed that is it so exactly real, so autonomous, so independent of our own hands. As long as we do not understand the synonymy between construction and autonomous reality, we misconstrue the factishes as another sort of social constructivism and not as what modified the theory of what it is to construct anything ${ }^{46}$.

I am suggesting that we consider Latour's factish as the acknowledged construction at the heart of many a conspiracy theory. The enunciative (and, often, performative) gesture that aims beyond the content of discourse to something else is the factish. Taking the factish seriously means countenancing a politics beyond the binary of fact and fiction. If conspiracy theory plays a role in the surge of so-called post-truth politics in Turkey and beyond, the "remedy" for such politics cannot simply be a turn to facts.

Assuming that facts will demystify the conspiracy theory is to assume that facts are the desired object of the theorist, but this is almost certainly a projection steeped in misunderstanding. As Latour suggests at the end of a laundry list of revolutions in western philosophical thought: "Each time the misinterpretation is the same: the naive belief in the other's naive belief $f^{47}$." Turkish media and media criticism are rife with discussion of the "ignorant" (cahil) audience and its manipulation by shows like Valley. Indeed the Valley enthusiasts and the Valley detractors noted above are likely to be seen as "ignorant" by many of the educated elite in Turkey. But the factish suggests that these publics may be up to something else: that the conspiracy logic so key to both the show and some political movements is not about proof but invitation. That insistence on facts precludes not only belonging but also understanding. 
This is a cautionary tale. As Latour notes, "the reason one should always beware with factishes is that the consequences are unseen, the moral order fragile, the social order unstable ${ }^{48}$." The Pana Film team felt the unwelcome return of conspiracy logic in an investigation that hints at such consequences. In February of 2017 that investigation, which was likely inspired by the Can't Not Say It accusations, and sought to determine whether the production firm had anything to do with the coup, was dismissed by the Terror and Organized Crime Investigation Bureau of the Republic Chief Prosecutor of Istanbul $^{49}$. While this suggests that factishes may lose potency in court, their overtures are quite powerful in other fields, and their progress from Valley to beyond certainly warrants attention. Indeed, the "coup" that inspired Valley's web site purchase might well be called a factish morphed to fact: an object of AKP fantasy and fascination that led to such antagonism of the Gülen Movement that it almost had to act. Turkey's political history is rich with real conspiracies that certainly began as theories of a sort, and richer still with theories about conspiracies yet to be revealed. The factish demands that we treat the latter with due care, developing an approach beyond the simple fact/fiction binary if we aim for political progress.

\section{BIBLIOGRAPHY}

BARBER, Karin (2007), The anthropology of texts, persons and publics: oral and written culture in Africa and beyond, New York, Cambridge University Press.

BRIGGS, Charles and Richard BAUMAN (1992), "Genre, intertextuality, and social power “, Journal of Linguistic Anthropology 2(2), p. 131-172.

BYFORD, Jovan (2011), Conspiracy Theories: A Critical Introduction, Palgrave Macmillan.

CARNEY, Josh and Valentina MARCELLA (2017), "Screens of satire and commons of resistance: the place and role of humor in the Gezi Park protests of Turkey”, Ridiculosa 24, p. 151-164.

CHRISTENSEN, Christian (2007), “ Concentration of ownership, the fall of unions and government legislation in Turkey”, Global Media and Communication 3(2), p. 179-199.

COMAROFF, Jean and John COMAROFF (2003), “Transparent fictions; or, the conspiracies of a liberal imagination: an afterword”, in: T. Sanders and H. G. West, eds., Transparency and Conspiracy: Ethnographies of Suspicion in the New World Order, Durham, North Carolina, Duke University Press, p. 287-299.

CREPS, Earl G. (1980), "The conspiracy argument as rhetorical genre”, Communication Studies, Northwestern University, p. 320.

FENSTER, Mark (2008 [1999]), Conspiracy theories: secrecy and power in American culture, Minneapolis, Minnesota, University of Minnesota Press.

FILKINS, Dexter (2016), “Turkey's thirty-year coup”, The New Yorker.

GUIDA, Michelangelo (2008), "The Sevres Syndrome and "komplo" theories in the Islamist and secular press”, Turkish Studies 9(1), p. 37-52.

TV/Series, 13 | 2018 
HANKS, William, F (1987), "Discourse genres in a theory of practice”, American Ethnologist 14(4), p. 668-692.

HDN STAFF (2014), “Report casts doubt on ex-president's death”, Hürriyet Daily News.

HENDRICK, Joshua D (2013), Gülen: the ambiguous politics of market Islam in Turkey and the world, New York, New York University Press.

HOFSTADTER, Richard (1952), The paranoid style in American politics and other essays, Cambridge, Massachusetts, Harvard University Press.

JAMESON, Fredric (2005), Archaeologies of the future: the desire called utopia and other science fictions, New York, Verso.

JUNG, Dietrich (2003), “The Sevres Syndrome: Turkish foreign policy and its historical legacy”, American Diplomacy 8(July).

LATOUR, Bruno (1997), “A few steps toward an anthropology of the iconoclastic gesture”, Science in Context 10(01), p. 63-83.

MARCUS, George E (ed. (1999), Paranoia within reason: a casebook on conspiracy as explanation, Chicago, University of Chicago Press.

SONG, Hoon (2006), "Seeing Oneself Seeing Oneself: White Nihilism in Ethnography and Theory", Ethnos: Journal of Anthropology 71(4), p. 470 - 488.

WARNER, Michael (2002), Publics and counterpublics, New York, Zone Books

WEST, Harry G and Todd SANDERS (eds.) (2003), Transparency and conspiracy: ethnographies of suspicion in the New World Order, Durham, North Carolina, Duke University Press.

YAZETE STAFF (2017), “Saçmalık son buldu... Kurtlar Vadisi Darbe için takipsizlik kararı verildi!” [Absurdity comes to an end... dismissal decision for Valley of the Wolves Coup], Yazete.

YAZETE STAFF (2017), “'Kurtlar Vadisi Darbe'ye hakaretten Nihat Doğan, Ömür Varol ve ekibine hapis istemi" [Prison motion against Nihat Doğan, Ömür Varol and team for defamation of Valley of the Wolves], Yazete.

\section{NOTES}

1. The TV serial Valley of the Wolves [Kurtlar Vadisi] premiered on Turkish private channel Show TV in January of 2003, and shifted to private channel Kanal D for its fourth and final season in the fall of 2005. It was followed by the blockbuster film Valley of the Wolves: Iraq [Kurtlar Vadisi: Irak, 2006] and then the short-lived serial Valley of the Wolves: Terror [Kurtlar Vadisi: Terör] in 2007. Next was serial Valley of the Wolves: Ambush [Kurtlar Vadisi: Pusu], which ran for 10 seasons, from 2007-2016, shifting among private channels Show TV, Star TV, TNT, ATV, and Kanal D. The franchise has thus far led to four more films: comedy spinoff Muro: Damn the Humanist Inside [ Muro: Nalet Olsun İçimdeki İnsan Sevgisine, 2008], and dramas Valley of the Wolves: Gladio [Kurtlar Vadisi: Gladio, 2009], Valley of the Wolves: Palestine [Kurtlar Vadisi: Filistine, 2011], and Valley of the Wolves: Homeland [Kurtlar Vadisi: Vatan, 2017]. The latter film tackles the topic of the July 2016 coup attempt, though producers clearly decided against using the "coup" name that had aroused such controversy. As of March 2018, there are rumors that serial Valley of the Wolves: Chaos [ Kurtlar Vadisi: Kaos] will start production in the summer of 2018 for a fall premier on an as-yet undesignated channel. Various elements of the Valley franchise have circulated outside of Turkey, with films and serials making their way to Germany, parts of the Balkans, the Turkic republics, and much of the Arab world. 
2. I spent four years in Istanbul between 2011 and 2015 working on various projects related to Turkish media, including one focused on Valley and its viewers.

3. Jean Comaroff and John Comaroff, "Transparent Fictions; or, the Conspiracies of a Liberal Imagination: an Afterword", in Transparency and Conspiracy: Ethnographies of Suspicion in the New World Order, ed. Todd Sanders and Harry G. West, Durham, North Carolina, Duke University Press, 2003, p. 287-299.

Mark Fenster, Conspiracy Theories: Secrecy and Power in American culture (Revised and updated ed.), Minneapolis, Minnesota, University of Minnesota Press, 2008.

Frederic Jameson, Archaeologies of the Future: the Desire Called Utopia and Other Science Fictions, New York, Verso, 2005.

Harry G West and Todd Sanders, ed. Transparency and Conspiracy: Ethnographies of Suspicion in the New World Order, Durham, North Carolina, Duke University Press, 2003.

4. George E Marcus ed., Paranoia Within Reason: a Casebook on Conspiracy as Explanation. Chicago, University of Chicago Press, 1999.

These trends are by no means mutually exclusive, and thinkers such as Fenster and Byford engage in aspects of all three.

5. Richard Hofstadter, The Paranoid Style in American Politics and Other Essays, Cambridge, Massachusetts, Harvard University Press, 1952.

6. Earl Creps, The Conspiracy Argument as Rhetorical Genre (PhD dissertation), Communication Studies, Northwestern University, 1980.

7. Jovan Byford, Conspiracy Theories: A Critical Introduction, Palgrave Macmillan, 2011.

8. Charles Briggs and Richard Bauman, "Genre, Intertextuality, and Social Power", Journal of Linguistic Anthropology, Vol. 2, No. 2, 1992, p. 131-172.

9. William F Hanks, "Discourse Genres in a Theory of Practice", American Ethnologist, Vol. 14, No. 4, 1987, p. 668-692.

10. Briggs and Bauman, p. 142-143.

11. Karin Barber, The Anthropology of Texts, Persons and Publics: Oral and Written Culture in Africa and Beyond, New York, Cambridge University Press, 2007, p. 44.

12. Michael Warner, Publics and Counterpublics, New York, Zone Books, 2002.

13. Christian Christensen, "Concentration of Ownership, the Fall of Unions and Government Legislation in Turkey", Global Media and Communication, Vol. 3, No. 2, 2007, p. 179-199.

14. I provide a portion of the Turkish original here because the specific acronym is important to the message.

15. Önür Varol, and Nihat Doğan, Sölyemezsem Olmaz [Can't not say it], Beyaz TV, 2016, 6 October.

16. There is little doubt among observers of Turkey that core elements of this organization were instrumental in the coup. Given the group's highly ambiguous structure and the broad nature of its outreach, however, it is inconceivable that the majority of those associated with the group through its various service, educational, media, commercial, and financial ventures were involved. This has not prevented the Turkish government from persecuting these associates and any other perceived opponents of the AKP during the post-coup State of Emergency. For more about the Gülen Movement and its ambiguous organizational logic, see Joshua D Hendrick, Gülen: the Ambiguous Politics of Market Islam in Turkey and the World, New York, New York University Press, 2013. For an overview of the Gülen Movement's relationship with the Turkish bureaucracy, the AKP, and some early hypotheses on the nature of the coup, see Dexter Filkins, "Turkey's ThirtyYear Coup", The New Yorker, 2016, 17 October.

17. Creps, p. 97.

18. "Bey" is a term of respect, somewhat close to the English "Mr.", but used with the first name rather than the last.

19. Yiğit Bulut, Bahadır Özdener, and Cüneyt Aysan, Sansürsüz [Uncensored], 24, 2012, 30 October. 20. Byford, p. 90. 
21. This is a rough translation, excising repetition and condensing the original.

Bedia Güzelce, Necati şaşmaz, Nur Aysan, Zübeyr şaşmaz, and Kenan Çoban, Skala: 'Kurtlar Vadisi Filistin' ekibi Skala'da [The Valley of the Wolves team on Skala], Habertürk, 2011, 24 January.

22. Can Dündar and Necati şaşmaz, Polat Alemdar NTV'de [Polat Alemdar on NTV], NTVMSNBC, 2011, 27 January 2011.

23. Though there are many cases of this throughout Valley, episode 115 provides a prominent example, when Polat warns the head of elders that Turkey faces an "even worse condition than Sèvres" if circumstances in the country don't change. Both Dietrich Jung ("The Sevres Syndrome: Turkish Foreign Policy and its Historical Legacy", American Diplomacy, Vol. 8, 2003) and Michelangelo Guida ("The Sevres Syndrome and "Komplo" Theories in the Islamist and Secular Press", Turkish Studies, Vol. 9, No. 1, 2008, p. 37-52) have written about the so-called "syndrome" and its circulation in contemporary Turkey.

24. Hofstadter, p. 29.

25. The disclaimer reads, “The people and institutions in our program's account of events from this dark, clouded Turkish valley are entirely a work of fiction." As of March 2018, the promotional trailer for Ambush season 8 was available at this link: https://tinyurl.com/hg535qf. The video says 11th season at the end because this was the 11th year of the franchise, but only the 8th season of the third TV serial, Ambush. Pana Film uses both sets of numbers to refer to the show at different times.

26. For more on Penguins and their role in the Gezi Park protests, see Josh Carney and Valentina Marcella, "Screens of Satire and Commons of Resistance: the Place and Role of Humor in the Gezi Park Protests of Turkey", Ridiculosa, Vol. 24, 2017, p. 151-164.

27. Hofstadter, p. 29.

28. Hofstadter, p. 35.

29. Hofstadter, p. 37.

30. Creps, p. 97.

31. Byford, p. 33.

32. Byford, p. 34.

33. Byford, p. 81.

34. Byford, p. 86.

35. HDN Staff, "Report Casts Doubt on Ex-President's Death", Hürriyet Daily News, 2014, 14 June.

36. I have assembled a brief, subtitled compilation of conspiracy-oriented clips from this episode and posted it at the following link: https://youtu.be/p3RDr7gD6lo.

37. Önür Varol, and Nihat Doğan, Sölyemezsem Olmaz [Can't not say it], Beyaz TV, 2016, 10 October. 38. Önür Varol, and Nihat Doğan, Sölyemezsem Olmaz [Can't not say it], Beyaz TV, 2016, 11 October. 39. Önür Varol, and Nihat Doğan, Sölyemezsem Olmaz [Can't not say it], Beyaz TV, 2016, 14 October. 40. One of the underlying motives for this theme was likely the YouTube ban in Turkey that took place at the time of the municipal elections on March 31st. The government had banned YouTube in an attempt to prevent further leaks revealing AKP corruption from the Gülen Movement. Valley E220 and E221, which broadcast at this period, suggest that mind control techniques were being used on the Turkish people through subliminal messages in social media and, therefore, that something drastic needed to be done to prevent this danger.

41. I recorded these lines and a brief sketch of our interaction on paper moments later, and then added this to my fieldnotes when I returned home that night.

42. Hoon Song, "Seeing Oneself Seeing Oneself: White Nihilism in Ethnography and Theory", Ethnos: Journal of Anthropology, Vol. 71, No. 4, 2006, p. 482 [p. 470 - 488].

43. Song, p. 482, italics in original.

44. Ambush specifically tackles the "lobby" in episode 212 (S08), where it is shown to be tied to both the Templars and the Gülen Movement. 
45. Bruno Latour, "A Few Steps Toward an Anthropology of the Iconoclastic Gesture", Science in Context, Vol. 10, No. 1, 1997, p. 63-83.

46. Latour, p. 69.

47. Latour, p. 81.

48. Latour, p. 80.

49. Yazete Staff, "Saçmalık Son Buldu... Kurtlar Vadisi Darbe için Takipsizlik Kararı Verildi! [Absurdity Comes to an End [...] Dismissal Decision for Valley of the Wolves Coup]," Yazete, 2017, 7 February. Weeks later, it was revealed that an indictment for defamation against the Can't Not Say It presenters had been filed based on complaints by Pana Film: Yazete Staff, “'Kurtlar Vadisi Darbe'ye Hakaretten Nihat Doğan, Ömür Varol ve Ekibine Hapis Istemi” [Prison Motion Against Nihat Doğan, Ömür Varol and Team for Defamation of 'Valley of the Wolves'], Yazete, 2017, 27 February.

\section{ABSTRACTS}

Shortly after the July 2016 coup attempt in Turkey, two talk show hosts suggested that the producers of the popular and long-lived Valley of the Wolves media franchise may have been involved with the coup. While these accusations received only minor traction in Turkish media, they are interesting both because they likely played a role in the franchise being investigated, and because they relied on a set of genre norms for conspiracy theory that had been popularized and codified in Turkey's public sphere by the Valley franchise itself. This paper investigates the relationship between conspiracy theory, Valley, and the show's public in a three-part argument. It begins by exploring the genre norms of conspiracy theory as they relate to Valley. Next, it turns to the performative function of conspiracy theory, suggesting that the Foucauldian approach to enunciation may explain an under examined role of such theorizing. Finally, it remarks on the ties between conspiracy theory, enunciation, and politics in the rise of what is often called the post-truth era.

Peu de temps après la tentative de coup d'État de juillet 2016 en Turquie, deux invités de talkshow ont émis l'idée que les producteurs de La Vallée des Loups, une franchise médiatique populaire en Turquie, auraient pu être impliqués dans le coup d'État. Si ces accusations n'ont connu qu'une faible couverture médiatique dans les médias turcs, elles sont intéressantes, parce qu'elles ont certainement joué un rôle dans l'ouverture d'une enquête sur cette franchise, et parce qu'elles reposaient sur un certain nombre de normes de genre de la théorie du complot, qui avaient été popularisées et codifiées par la série La Vallée des loups elle-même. Cet article se penche sur la relation entre la théorie du complot, La Vallée des loups, et le public de la série, en trois parties. Il commence par explorer les normes de genre de la théorie du complot, dans leur rapport à La Vallée des loups. Ensuite, il se tourne vers la fonction performative de la théorie du complot, en faisant l'hypothèse que l'approche foucaldienne de l'énonciation pourrait expliquer un rôle sous-étudié de ces théories. L'auteur conclut par une série de remarques sur les liens entre théorie du complot, énonciation et politique, dans le contexte de la montée en puissance de l'ère de la « post-vérité ». 


\section{INDEX}

Mots-clés: complot, La Vallée des loups, post-vérité, tentative de coup d'État de 2016 en Turquie, Turquie, genre, télévision, culture populaire

Keywords: conspiracy, Valley of the Wolves, post-truth, 2016 Turkish coup attempt, genre, television, media, Turkey, popular culture

\section{AUTHOR}

\section{JOSH CARNEY}

Josh Carney is Assistant Professor in the Department of Sociology, Anthropology, and Media Studies at the American University of Beirut. His work focuses on media from Turkey, with recent projects on popular television, cinematic censorship, and the role of media screens in public demonstrations. He received his $\mathrm{PhD}$ in Communication and Culture from Indiana University in 2015. His personal website (with links to some publications) is joshlcarney.com.

Josh Carney est maître de conférences au département de sociologie, anthropologie et journalisme à l'université américaine de Beyrouth. Ses travaux portent sur les médias en Turquie, et ses projets les plus récents concernent la télévision et la culture populaire, la censure cinématographique, et le rôle des médias d'écran dans les mobilisations politiques. Il a soutenu sa thèse de doctorat au département de communication et culture à l'université d'Indiana en 2015. Voici un lien vers son site personnel (avec des liens vers quelques publications) : joshlcarney.com 